\title{
Pajak Penghasilan Pada Subjek Penghasilan Di Bawah Umur Melalui Media Sosial
}

\author{
Retno Sari Dewi ${ }^{1}$ \\ ${ }^{1}$ Fakultas Hukum, Universitas Tulungagung \\ ${ }^{\Omega}$ Surel Koresponden: sarie.soegito@gmail.com
}

\begin{abstract}
:
The unregulated income tax for underage tax subjects who use social media in Indonesia needs attention from the government. The increasing number of social media users by underage tax subjects who currently do not receive supervision. The self-assessment-based income tax collection system is also an obstacle to this problem. In the study in this article using the socio-legal research method which examines the limitations of legal sources

Normative aspects and often legal issues are related to social and political contexts in empirical aspects. The findings from this study required policy formulation: mapping data on underage tax subjects with income generation using social media content, collaborating with various related parties and conducting a review of the income tax collection system.

Keywords: income tax; tax subject; children; social media;
\end{abstract}

\begin{abstract}
Abstrak:
Pajak penghasilan yang tidak diatur untuk subjek pajak di bawah umur yang menggunakan media sosial di Indonesia perlu mendapat perhatian dari pemerintah. Meningkatnya jumlah pengguna media sosial oleh subjek pajak di bawah umur yang saat ini tidak mendapat pengawasan. Sistem pemungutan pajak penghasilan berbasis penilaian sendiri juga menjadi kendala bagi masalah ini. Dalam kajian pada artikel ini menggunakan metode penelitian sosio-hukum yang mengkaji keterbatasan sumber hukum. Aspek normatif dan seringkali persoalan hukum dikaitkan dengan konteks sosial dan politik dalam aspek empiris. Temuan dari studi ini membutuhkan perumusan kebijakan, memetakan data subjek pajak di bawah umur dengan perolehan pendapatan menggunakan konten media sosial, bekerja sama dengan berbagai pihak terkait, dan melakukan review terhadap sistem pemungutan pajak penghasilan.
\end{abstract}

Kata Kunci: pajak penghasilan; subjek pajak; anak; media sosial;

Submit : 20-11-2020

Accept : 29-11-2020

Doi: http://doi.org/10.56087/aijih.v23i2.54

\section{PENDAHULUAN}

Bagi Negara pajak adalah salah satu sumber pembiayaan guna menunjang keberlangsungan hidup sebuah negara. Sehingga pemerintah menempatkan kewajiban perpajakan sebagai salah satu pewujudan kewajiban kenegaraan yang merupakan sarana dalam pembiayaan negara dalam pembangunan nasional guna tercapainya tujuan negara. Pajak ialah iuran yang dilakukan oleh masyarakat kepada 
kas negara berdasarkan undang - undang yang berlaku (dapat dipaksakan) dengan tidak mendapatkan jasa timbal balik (kontra prestasi) secara langsung dapat ditunjukan dan atau digunakan untuk membiayai pengeluaran umum pemerintah. ${ }^{1}$ Hal ini sesuai dengan bunyi Pasal 23A yaitu pajak dan pungutan lain yang bersifat memaksa untuk keperluan negara diatur dengan undang-undang. Jadi, setiap pungutan yang dikenakan kepada warga negara harus jelas harus jelas dasar hukumnya. Fungsi pajak ada dua, yaitu fungsi budgeter dan fungsi regulerend, Fungsi budgeter adalah pajak sebagai sumber penerimaan negara, dan fungsi regulerend yaitu pajak digunakan untuk mengatur masyarakat, baik dibidang ekonomi, sosial, maupun politik dengan tujuan tertentu. ${ }^{2}$ Fenomena internet telah menyebar ke seluruh dunia termasuk di Indonesia. Beberapa tahun terakhir ini penggunaan jasa internet terutama di Indonesia meningkat dengan pesat. Jika di dunia Indonesia menduduki peringkat keempat dengan penduduk terbanyak di dunia, maka untuk pengguna internet Indonesia menduduki peringkat keenam sebagai pengguna terbanyak. Data tersebut sesuai dengan survei yang dilakukan oleh Asosiasi Penyelenggara Jaringan Internet Indonesia (APJII) mengungkap bahwa lebih dari setengah penduduk Indonesia kini telah terhubung ke internet. Sebagai upaya untuk mendapatkan pemasukan tambahan bagi negara, pemerintah melalui Direktorat Jendral Pajak (DJP) memiliki rencana untuk menarik pajak bagi pengguna akun media sosial atau para selebgram yang menjual, dan mempromosikan produk di media sosial. Media sosial yang dimaksud di antaranya adalah Facebook, Instagram, dan lainnya, termasuk Youtube.

Media sosial adalah sebuah media online, dengan para penggunanya bisa dengan mudah berpartisipasi, berbagi, dan menciptakan isi meliputi blog, jejaring sosial, wiki, forum dan dunia virtual, pergaulan, jarak dan waktu bukan lagi masalah, lebih mudah dalam mengekspresikan diri, penyebaran informasi dapat berlangsung secara cepat, biaya lebih murah Seiring dengan kemajuan teknologi begitu pula

\footnotetext{
${ }^{1}$ Ahmad Fariez Danial., (2018). 'Analisis Pemahaman Pajak Penghasilan Dan Sanksi Pajak Pada Wajib Pajak Orang Pribadi (WP-OP) Pegawai Ud Petis Udang Di Kampung Petis Desa Gumeng Bungah Gresik' (Universitas Islam Negeri Sunan Ampel Surabaya) Retrivied: https://bit.ly/3hby5ub

2 Fadiyah Ramadhani Putri, (2020). 'Kebijakan Pemerintah Dalam Pengenaan Pajak Penghasilan Pelaku Usaha Asing Game Online', Https://Jurnal.Narotama.Ac.Id/Index.Php/Hukumbisnis/Article/View/1014, 4.1, 254-70 <https://doi.org/10.31090/hukumbisnis.v4i1.1014>.
} 
dengan media sosial. ${ }^{3}$ awalnya hanya berupa sarana untuk untuk bersosialisasi berkembang menjadi sarana kegiatan berbisnis.

Asosiasi Penyelenggara Jasa Internet Indonesia (APJII) telah melalukan survei mengenai penetrasi internet dan perilaku pengguna internet di Indonesia. Hasil survei tersebut mengungkapkan bahwa pengguna internet di Indonesia mencapai 171,17 juta. Ini berarti jumlah pengguna internet sebesar $64,8 \%$ dari total penduduk Indonesia. ${ }^{4}$ Tidak jarang pemasaran sebuah produk sangat tergantung dengan strategi market artis / seseorang yang menjadi trendsetter. Dalam dunia ekonomi bisnis peran ini dimainkan oleh "influencer". Social media influencers were individuals who actively used their social media accounts and often involved in a certain topic, as well as providing new information. ${ }^{5}$ Ada beberapa ahli yang berpendapat bahwa pengaruh media sosial akan meningkat dari tahun ke tahun, sejak penggunaan media sosial sebagai media pemasaran semakin populer di Indonesia dengan menggadeng seorang influencer Influencer atau orang yang dapat mempengaruhi orang lain, bisa dipercaya, serta memiliki pengikut yang banyak kini di media sosial menjadi profesi dengan pendapatan yang cukup menjanjikan.

Realitasnya saat ini yang terjadi jumlah anak-anak membuat video dan menggunggahnya di akun Youtube, video yang mereka unggah biasanya berisikan kegiatan sehari-hari dan berbagi cerita. Dari unggahan tersebut, mereka mendapatkan viewer dan subscriber yang mana kedua hal tersebut pengaruh terhadap penghasilan mereka. Semakin banyak video mereka ditonton dan meningkatknya jumlah pengikut sebanding dengan peningkatan pendapatan mereka. Para influencer cilik melalui konten yang dihasilkan melalui Youtube memunculkan fenomena miliarder-miliarder cilik. Salah satu contohnya adalah Zara Nugroho Lewat channel YouTube tersebut, Zara berhasil mendapatkan pundi-pundi

\footnotetext{
${ }^{3}$ Anang Sugeng Cahyono, (2016). 'Pengaruh Media Sosial Terhadap Perubahan Sosial Masyarakat Di Indonesia', Jurnal IImu Sosial \& IImu Politik Diterbitkan Oleh Fakultas Ilmu Sosial \& Politik, Universitas Tulungagung, 9.1, 140-57

${ }^{4}$ Sona Yani and Menik Siwi, (2020). 'Analisis Penggunaan Media Sosial Dan Sumber Belajar Digital Dalam Pembelajaran Bagi Siswa Digital Native Di SMAN 2 Painan', Jurnal Pendidikan Ekonomi, 13.1, 1-7 <https://doi.org/10.17977/um014v13i12020p001>.

${ }^{5}$ Atika Hermanda., (2019). Ujang Sumarwan., and Netti Tinaprilla., 'The Effect of Social Media Influencer on Brand Image, Self-Concept, and Purchase Intention', Journal of Consumer Sciences, 4.2 (2019), 77 <https://doi.org/https://doi.org/10.29244/jcs.4.2.76-89>.
} 
uang sekitar US\$ 150 ribu (Rp 2,1 miliar) hingga US\$2,4 juta (Rp33 miliar) per tahun. Influencer melalui kanal youtube biasa dikenal dengan youtuber.

Memahami bahwa negara Indonesia adalah negara hukum, maka terdapat banyak persoalan yang terjadi seiring dengan dinamika implementasi hukum terhadap sektor ekonomi bisnis berbasis media sosial. Yang menarik ketika membahas tentang pengenaan pajak penghasilan terhadap pelaku ekonomi bisnis digital ini adalah bagaimana pemberlakuan pajak penghasilan terhadap subjek pajak yakni influencer yang menjadi brand ambassador sebuah produk dengan terikat nilai kontrak tertentu dengan sebuah perusahaan yang membutuhkan jasanya belum jelas. Meskipun sudah ada regulasi yang mengatur tentang pendapatan para influencer sebagai subjek pajak, akan tetapi hukum tentang pajak penghasilan secara detail, implementatif dan lebih spesifik seperti pengaturan subjek pajak bagi dibawah umur masih sulit diukur dan identifikasi. Pertanyaan lain seperti mengapa harus membahas influencer sebagai subjek pajak dibawah umur yang menjadi fokus dalam penelitian ini? Jawaban yang menjadi argument kuat adalah selama ini belum jelas implementasi tentang pemberlakuan pajak penghasilan terhadap artis/influencer sebagai subjek pajak dibawah umur.

Mengacu dari beberapa fenomena diatas maka sudah seharusnya menjadi perhatian Direktoral Jendral Pajak. Penghasilan dari youtuber cilik tersebut bisa berpotensi dijadikan salah satu sumber penerimaan negara dari sektor non migas. Pendapatan youtuber diatas telah memenuhi persyaratan secara subyekt dan obyektif untuk dapat dikenai Pajak Penghasilan. Hampir sebagaian besar youtuber anak yang memperoleh penghasilan dari konten yang sekaligus menjadi subyek pajak dibawah umur (dalam prespektif UUPPh) masih berada dibawah orangtua. Dan dari berbagai fakta dilapangan tidak jarang youtuber cilik tersebut dimanajeri oleh orang tua sendiri. Dalam konteks ini terdapat dua subyek pajak yakni pertama youtuber cilik masuk kedalam subyek pajak dibawah umur sedangkan orang tua merupakan subyek pajak dimana mereka berprofesi sebagai manajer/agen dari youtuber cilik tersebut. Jika Subyek Pajak dibawah umur diikutsertakan pemungutan pajak penghasilan berdasarkan UUPPh maka akan terjadi ambiguitas pemungutan Subyek Pajak. Mengingat penghasilan dari subyek pajak dibawah umur menggunakan media media sosial tersebut cukup besar dan semakin banyak anak dibawah umur yang membuat 
konten dan menjadi youtuber berpenghasilan perlu kiranya pemerintah mengatur tata kelola pemungutan pajak penghasilan terhadap subyek pajak dibawah umur.

Terdapat alasan mendasar mengapa aparat pajak perlu lebih memburu pajak penghasilan dari orang-orang kaya, diantaranya: 1) Nominal pajak mereka lebih besar dibandingkan dengan wajib pajak biasa. Mungkin saja pajak satu orang kaya setara dengan lima wajib pajak biasa. Hal tersebut tentu menjadi nilai akumulasi yang besar jika dihitung secara nasional. 2) Aspek kepatuhan pajak dari orang-orang kaya sepertinya masih sangat minim. Padahal, banyak orang kaya yang semestinya tidak hanya terjerat oleh PPh pribadi tapi juga pajak melalui dunia usaha yang digelutinya. 3) Prinsip keadilan dalam kehidupan bernegara. Selain fungsi budgeter atau fungsi penerimaan, pajak pada dasarnya juga melaksanakan fungsi redistribusi pendapatan dari masyarakat yang mempunyai kemampuan ekonomi yang lebih tinggi kepada masyarakat yang kemampuannya lebih rendah. 4) Pajak masih menjadi sumber utama untuk pendanaan pembangunan. 5) Logika di balik lemahnya tingkat kepatuhan wajib pajak tidak lain karena adanya prinsip bahwa semua regulasi dan perundangan adalah untuk disiasati, bukan ditaati. Hal ini tentu menjadi semakin rancu ketika ketika perpajakan menjadi sumber utama di era otonomi daerah untuk meningkatkan pendapatan asli daerah (PAD). ${ }^{6}$

Pajak Penghasilan adalah pajak negara yang dikenakan terhadap setiap tambahan ekonomis yang diterima oleh wajib pajak, baik yang berasal dari Indonesia maupun luar negeri, yang dapat dipakai untuk konsumsi atau untuk menambah kekayaan Wajib Pajak yang bersangkutan Pajak Penghasilan (PPh) diatur oleh Undang-Undang Nomor 7 Tahun 1984 dan mengalami perubahan hingga ddisempurnakan dengan Undang-Undang Nomor 36 Tahun 2008. Berkaitan dengan berbagai temuan dan ketidakjelasan pengenaan pajak penghasilan tehadap subjek pajak dibawah umur yang memperoleh penghasilan dengan pemanfaatan media sosial youtube khususnya maka penulis tertarik untuk membahas mengenai bagaimana tinjauan yuridis UUPPh terhadap penghasilan subyek pajak dibawah umur melalui konten media sosial youtube. Tujuan dari penelitian ini adalah untuk mengidentifikasi dan menganalisis

\footnotetext{
${ }^{6}$ Candra Mustika, (2012). 'Pajak Penghasilan Di Indonesia (Peraturan,Perhitungan Dan Upaya Peningkatan Potensi Penerimaan) Dan Kaitannya Dengan Invetsasi Di Indonesia', Mankeu, Vol. 1, 227-38.
} 
tentang tinjauan yuridis UUPPh terhadap penghasilan subyek pajak dibawah umur melalui konten media sosial youtube.

\section{METODE}

Penelitian ini menggunakan metode sosio legal research. Sosio-legal, bukanlah sosiologi hukum, dan tidak direduksi menjadi penelitian yuridis-empiris, sosio-legal mensyaratkan kemampuan penelitian hukum normatif secara baik. Faktor itu antara lain, pertama, keterbatasan sumber hukum untuk penelitian hukum teks itu sendiri. Kedua, seringkali masalah-masalah hukum terkait dengan konteks sosial dan politiknya, dimana pendekatan sebatas ranah teoritikal maupun praktikal tidak mampu menjawab berbagai masalah yang demikian rumit. Ketiga, semakin menguatnya keinginan untuk menggapai rasa keadilan yang lebih substantif dan berpihak pada kepentingan publik secara luas (social justice) dibandingkan sebatas keadilan formal versi peraturan perundang-undangan (legal justice). ${ }^{7}$ Yang menjadi fokus pembahasan dalam artikel ini berkaitan subyek pajak, objek pajak, kewajiban serta hak subyek pajak secara normative mengkaji UUPPh dan secara empiris mengaji fenomena penggenaan pajak terhadap subyek hukum pajak dibawah umur.

\section{HASIL}

Tabel 1. Penghasilan Subyek Pajak Dibawah Umur Melalui Media Sosial

\begin{tabular}{|c|c|c|c|c|c|}
\hline No & Nama & Usia & Penghasilan & Tahun & $\begin{array}{l}\text { Media } \\
\text { Sosial } \\
\end{array}$ \\
\hline 1 & Aqilla CP & 7 tahun & $\begin{array}{l}\text { US } \$ 170 \text { ribu (2,3 miliar) - } \\
\text { US } \$ 2,7 \text { juta ( } 37 \text { miliar). }\end{array}$ & Mei 2020 & Youtube \\
\hline 2. & $\begin{array}{l}\text { Zara } \\
\text { Nugroho }\end{array}$ & 5 tahun & $\begin{array}{c}\text { US\$ } 150 \text { ribu (Rp 2,1 miliar) } \\
\text { hingga US\$2,4 juta (Rp33 } \\
\text { miliar) per tahun. }\end{array}$ & Mei 2020 & Youtube \\
\hline 3 & $\begin{array}{l}\text { Hana } \\
\text { Callista }\end{array}$ & 5 tahun & $\begin{array}{c}\text { US\$ } 94 \text { ribu (Rp } 1,3 \text { miliar) } \\
\text { hingga US } \$ 1,5 \text { juta (Rp } 21 \\
\text { miliar) }\end{array}$ & Mei 2020 & Youtube \\
\hline 4. & Shinta & 8 tahun & $\begin{array}{c}\text { US\$ } 38 \text { ribu (Rp532 juta ) - } \\
\text { US\$612 ribu }(8,5 \text { miliar })\end{array}$ & Mei 2020 & Youtube \\
\hline 5. & Lifia Niala & $\begin{array}{l}8 \text { dan } 5 \\
\text { tahun }\end{array}$ & $\begin{array}{l}\text { US\$ } 35 \text { ribu (Rp490 juta) - } \\
\text { US\$ } 564 \text { ribu (7,8 miliar) }\end{array}$ & Mei 2020 & Youtube \\
\hline
\end{tabular}

\footnotetext{
${ }^{7}$ Herlambang P Wiratraman, Penelitian Sosio-Legal Dan Konsekuensi Metodologisnya, Https://Herlambangperdana.Files.Wordpress.Com/2008/06/Penelitian-Sosio-Legal-Dalam-Tun.Pdf, 2008.
} 
Dari tabel 1 dapat diketahui bahwa peringkat pertama Pemilik nama asli Aqilla CP, saat ini berusai 7 tahun memasuki kelas 2 SD nama channel YouTube Aqilla's Diary memiliki pengikut lebih dari 1 juta dan berpenghasilan US $\$ 170$ ribu (2,3 miliar) US $\$ 2,7$ juta (37 miliar). Selanjutnya pada peringkat kedua ada Zara Nugroho atau lebih dikenal dengan "Zara Cute "ini sudah mendapatkan 2,79 juta pengikut dan berhasil mendapatkan penghasilan sekitar US\$ 150 ribu (Rp 2,1 miliar) hingga US\$ 2,4 juta (Rp33 miliar) per tahun.Peringkat ketiga ada Hana Callista kanal YouTube miliknya dengan nama Hana Callista hingga kini sudah mencapai lebih dari 3 juta pengikut t berhasil membuatnya berpenghasilan sekitar US\$ 94 ribu (Rp 1,3 miliar) hingga US\$1,5 juta (Rp 21 miliar) per tahun. Peringkat ke empat YouTuber cilik lain yang Little Princess Shinta, memiliki 2 juta lebih pengikut penghasilannya diprediksi sekitar US\$ 38 ribu (Rp532 juta ) - US\$612 ribu (8,5 miliar) per tahun. Perikat kelima dan mendapatkan penghasilan miliaran rupiah selanjutnya adalah Lifia Niala memiiliki pengikut lebih dari 2 juta penghasilannya per tahun diperkirakan US\$ 35 ribu (Rp490 juta)-US\$ 564 ribu (7,8 miliar) per tahun. Melihat fakta bahwa maraknya penggunaan media sosial yang secara langsung berdampak penghasilan maka perlu kiranya pemerintah memberikan perhatian sekaligus pengaturan tentang penerimaan pajak terhadap subyek pajak yang masih dibawah umur.

Dengan mengadopsi self assessment system sebagai sistem pemungutan pajak nasional. Sistem pemungutan pajak dengan self assessment system, yang pada prinsipnya menuntut Wajib Pajak untuk lebih bertanggungjawab dalam melaksanakan kewajiban perpajakannya, berkaitan dengan beban mengestimasi, menunaikan dan memberitahukan pajak sendiri Self Assessment System juga digunakan dalam regulasi pajak penghasilan yang diatur dalam UU No.36 Tahun 2008 tentang Pajak Penghasilan.

Dalam UUPPh pengaturan mengenai definisi subyek hukum merujuk pada pasal 2,1. Subyek Pajak Penghasilan terhadap Orang Pribadi, diantaranya ;(1). Subyek PajakPajak Penghasilan Dalam Negeri.(2). Subyek Pajak-Pajak Penghasilan Luar Negeri. Kewajiban Subyek Pajak Badan, yang didirikan dan bertempat kedudukan di Indonesia, kewajiban pajak subyektifnya dimulai pada; (1). saat badan tersebut 
didirikan, atau (2). bertempat kedudukan di Indonesia, dan (3). berakhir pada saat dibubarkan atau tidak lagi bertempat kedudukan di Indonesia. Adapula warisan belum dibagi menggantikan yang berhak, dan Bentuk Usaha Tetap dengan kriteria subyek pajak orang pribadi merujuk pasal 1 ayat 3 yang menjadi subyek adalah orang yang berada di Indonesia 183 (seratus delapan puluh tiga) dalam jangka waktu 12 bulan di Indonesia. Sedangkan untuk Wajib Pajak adalah orang pribadi atau badan yang sudah memenuhi ketentuan definisi sebagai subjek pajak dan mendapatkan penghasilan dari objek pajak. Bahwa kedua unsur tersebut harus dipenuhi untuk menjadi Wajib Pajak adalah Subjek Pajak dan Objek Pajak. Selain itu subyek pajak bagi orang yang sudah memiliki NPWP dan wajib untuk membayar pajak, karena pengertian yang terkandung di dalam regulasi dan menjelaskan apabila seseorang memiliki NPWP pun dapat dikategorikan sebagai Wajib Pajak apabila benar-benar sudah mempunyai hak dan kewajiban perpajakan.

Hak wajib pajak mengenai kepatuhan, dapat dikatakan mencakup lima pendekatan tersebut adalah: 1) dari sudut pandang politisi menggunakan istilah tersebut untuk mendukung kebijakan tertentu dan peraturan yang didorong oleh politik. 2) Tinjauan pemerintah dan departemen perbendaharaan pemerintah sering menggunakan istilah tersebut untuk mendukung perpaduan peraturan ekonomi dan peraturan yang didorong oleh politik. 3) dari sudut pandang pengadilan dan sistem hukum biasanya memiliki interpretasi hukum yang ketat terhadap hak dan penerapannya terhadap perpajakan. 4) dari sudut pandang administrasi perpajakan dalam segala bentuknya sering menggunakan istilah tersebut untuk membingkai cara aturan administrasi sistem perpajakan diimplementasikan dan ditafsirkan. 5) Dari sudut pandang administrator pajak, ombudsman dan wajib pajak juga menggunakan istilah tersebut untuk menggambarkan standar layanan, perilaku dan aspek isi hubungan antara wajib pajak dan administrasi perpajakan. ${ }^{8}$ Pengaturan mengenai Hak dasar wajib pajak mencakup diantaranya: 1) Hak untuk diberi informasi, dibantu dan didengar, 2) hak banding, 3) hak untuk tidak membayar tidak lebih dari jumlah pajak yang seharusnya, 4) hak atas privasi dan hak atas kerahasiaan. Untuk kewajiban wajib pajak pun diantaranya: 1) kewajiban untuk

\footnotetext{
${ }^{8}$ L.Y. Hari Sih Advianto, Pengakuan Dan Perlindungan Hukum Hak Hak Wajib Pajak Dalam Sistem Hukum Pajak Indonesia, Simposium Nasional Keuangan Negara, 2018.
} 
jujur, 2) kewajiban untuk kooperatif, 3)kewajiban untuk memberikan informasi dan dokumen, 4) kewajiban untuk menyimpan catatan, 5) kewajiban membayar pajak tepat waktu.

\section{IMPLEMENTASI UU PPh TERHADAP SUBYEK PAJAK DIBAWAH UMUR}

Menurut UU PPh No. 36 Tahun 2008 Pasal 7 disebutkan penghasilan anak yang belum dewasa dari mana pun sumber penghasilannya dan apapun sifat pekerjaannya digabung dengan penghasilan orang tuanya dalam tahun pajak yang sama. dan di Pasal 8 juga menyebutkan: Sistem pengenaan pajak berdasarkan regulasi tersebut memberi gambaran bahwa keluarga merupakan satu kesatuan ekonomis, artinya penghasilan atau kerugian dari seluruh anggota keluarga dijadikan sebagai satu kesatuan yang dikenai pajak dan pemenuhan kewajiban pajaknya dilakukan oleh kepala keluarga.

Sesuai Rumusan Hasil Rapat Pleno Kamar Perdata Mahkamah Agung RI sebagaimana tertuang dalam Surat Edaran Mahkamah Agung RI Nomor 07 Tahun 2012 tentang Rumusan Hasil Rapat Pleno Kamar Mahkamah Agung Sebagai Pedoman Pelaksanaan Tugas Bagi Pengadilan, secara tegas disebutkan bahwa "dewasa" adalah cakap bertindak dalam hukum, yaitu orang yang telah mencapai umur 18 (delapan belas) tahun atau telah kawin. ${ }^{9}$ Apabila youtuber tersebut belum mencapai batas usia tersebut maka segala perbuatan hukumnya dikuasakan kepada orang tua, termasuk dalam hal pajak penghasilan.

Terkait dengan profesi youtuber cilik tersebut masuk kedalam penghasilan dari pekerjaan bebas merujuk pasal 4 UUPPh. Berikut ini akan diuraikan penggolongan objek pajak yang biasanya dimiliki oleh seorang youtuber:

1. Penghasilan Dari Jasa Sehubungan Dengan Pekerjaan Bebas Dalam PP No. 23 Tahun 2018 diatur bahwa:

- Pasal 2 ayat (3) huruf a, tidak termasuk penghasilan dari usaha yang dikenai Pajak Penghasilan yang bersifat final sebagaimana dimaksud pada ayat (1) adalah penghasilan yang diterima atau

\footnotetext{
9 'Istilah “Anak”, “Anak”, Dan “Belum Dewasa” - Pengadilan Negeri Kediri', Http://PnKediri.Go.Id/Index.Php/Component/K2/Item/230-Istilah-Anak-Dan-Belum-Dewasa.HtmI, 2017.
} 
diperoleh Wajib Pajak orang pribadi dari jasa sehubungan dengan pekerjaan bebas;

- Pasal 2 ayat (4) huruf b, jasa sehubungan dengan pekerjaan bebas sebagaimana dimaksud pada ayat (3) huruf a meliputi: huruf a, pemain musik, pembawa acara, penyanyi, pelawak, bintang film, bintang sinetron, bintang iklan, sutradara, kru film, foto model, peragawan/peragawati, pemain drama, dan penari;

- Dengan demikian, penghasilan yang diterima atau diperoleh Artis dari jasa sehubungan dengan pekerjaan bebas bukan merupakan objek Pajak Penghasilan Final dalam PP No. 23 Tahun 2018, sehingga dalam penghitungan pajaknya akan menggunakan Tarif Pasal 17 UU PPh.

2. Penghasilan Sehubungan Dengan Kegiatan Usaha

Selain penghasilan dari jasa sehubungan dengan pekerjaan bebas, beberapa kategori youtuber yang memproduksi dan menjual barang-barang seni seperti pelukis, pemahat, pematung dan sejenisnya dapat memperoleh penghasilan atas penjualan barang seni tersebut.Sehingga berdasarkan PP no. 23 Tahun 2018, atas penghasilan dari kegiatan usaha tersebut dapat dikenakan PPh Final sesuai PP No. 23 Tahun 2018 atau menggunakan perhitungan tarif Pasal 17 UU No. 36 Tahun 2008, tergantung dari jumlah peredaran bruto dalam 1 tahun pajak dan pilihan dari artis itu sendiri. Demikian juga untuk kegiatan usaha lainnya selain barang seni yang dimiliki oleh artis tersebut.Misal, artis memiliki usaha penjualan kue atau salon. Atas kegiatan usaha tersebut, dapat dikenakan PPh final sesuai dengan PP 23 untuk omzet dari penjualan kue atau salon tidak lebih dari 4,8 miliar.

3. Penghasilan Sehubungan Pekerjaan, Jasa Dan/Atau Kegiatan Dari Pemberi Kerja / Pihak Yang Ditunjuk Sebagai Pemotong Atau Pemungut Pajak.

Youtober juga dapat memperoleh penghasilan sehubungan dengan pekerjaan, jasa dan/atau kegiatan dari pemberi kerja yang merupakan objek pemotongan PPh Pasal 21 sebagaimana tertuang dalam penjelasan pasal 21 ayat (1) huruf a Undang-Undang No. 36 Tahun 2008 dikategorikan sebagai 
Bukan Pegawai yang objek penghasilannya berupa honorarium dari pemberi kerja.

4. Penghasilan Sebagaimana Yang Dimaksud Dalam Pasal 23 UU No. 36 Tahun 2008, Misalnya Dalam Bentuk Royalti.Dalam Pasal 23 UU No. 36 Tahun 2008 disebutkan bahwa :

- Atas penghasilan tersebut di bawah ini dengan nama dan dalam bentuk apa pun yang dibayarkan, disediakan untuk dibayarkan, atau telah jatuh tempo pembayarannya oleh badan pemerintah, subjek pajak badan dalam negeri, penyelenggara kegiatan, bentuk usaha tetap, atau perwakilan perusahaan luar negeri lainnya kepada Wajib Pajak dalam negeri atau bentuk usaha tetap, dipotong pajak oleh pihak yang wajib membayarkan.

Selanjutnya, sebagaimana dijelaskan dalam Penjelasan Pasal 4 ayat (1) Huruf H UU 36 Tahun 2008: Royalti adalah suatu jumlah yang dibayarkan atau terutang dengan cara atau perhitungan apa pun, baik dilakukan secara berkala maupun tidak, sebagai imbalan atas: Penggunaan atau hak menggunakan hak cipta di bidang kesusastraan, kesenian atau karya ilmiah, paten, desain atau model, rencana, formula atau proses rahasia, merek dagang, atau bentuk hak kekayaan intelektual/industrial atau hak serupa lainnya;Dalam hal Artis memperoleh Royalti atas transaksi dengan pihakpihak sebagaimana tersebut di atas, maka Artis akan dikenakan pemotongan PPh Pasal 23 sebesar 15\% dan bersifat tidak final. Pajak profesi youtuber pada dasarnya mempunyai hak dan kewajiban perpajakan sesuai dengan ketentuan peraturan perundang-undangan perpajakan.

Olehnya perlu mendapatkan perhatian berkaitan dengan youtuber dalam menunaikan kewajiban membayar pajak penghasilan. Dalam hal ini, perlu dilihat adalah peran orang tua dari youtuber tersebut apabila orang tua murni hanya berkedudukan sebagi orang tua dan memiliki perkerjaan lain maka secara normative menurut aturan pembayaran serta pelaporan pajak penghasilan yang dihasilkan oleh youtuber cilik tersebut dijadikan satu dan ditanggung oleh orang tua. Namun aturan tersebut tidak dapat dikenakan apabila orang tua dari youtuber tersebut sekaligus sebagai manajer, maka untuk menunaikan kewajiban dalam pajak 
penghasilan harus dibedakan. Pajak penghasilan sebagai seorang manajer dalam hal ini sebagai pekerja yang bekerja untuk Youtuber Cilik tersebut, dan pajak penghasilan sebagai wali dari youtuber cilik tersebut.

\section{KESIMPULAN DAN SARAN}

Belum diaturnya ketentuan secara adil tentang pajak penghasilan terhadap subyek pajak dibawah umur oleh pemerintah dapat segera dilakukan dengan beberapa alternative proses perumusan kebijakan yang pertama pemetaan data subyek pajak dibawah umur dengan perolehan penghasilan menggunakan konten media sosial, yang kedua pemerintah perlu berkolaborasi dengan semua pihak terkait ketentuan pajak penghasilan terhadap subyek apajak dibawah umur yang menggunakan media sosial, ketiga melihat berbagai kendala terhadap pemungutan pajak terhadap subyek pajak dibawah umur pemerintah perlu melakukan tinjauan terhadap sistem pemungutan pajak penghasilan self assement menjadi official assesment, yang ke empat pemerintah dapat membuat peraturan turunan dari undang-undang yang menegaskan pokok permasalahan tentang pemungutan pajak penghasilan bagi subyek pajak dibawah umur. Oleh sebab itu perlu dilakukan penelitian lebih lanjut untuk membangun persepsi dan kesadaran masyarakat dalam berpartisipasi terhadap pembangunan nasional melalui pembayaran pajak penghasilan.

\section{REFERENSI}

Advianto, L.Y. Hari Sih, (2018). Pengakuan Dan Perlindungan Hukum Hak Hak Wajib

Pajak Dalam Sistem Hukum Pajak Indonesia, Simposium Nasional Keuangan Negara.

Cahyono, Anang Sugeng, (2016). 'Pengaruh Media Sosial Terhadap Perubahan Sosial

Masyarakat Di Indonesia', Jurnal Ilmu Sosial \& Ilmu Politik Diterbitkan Oleh Fakultas

Ilmu Sosial \& Politik, Universitas Tulungagung, 9, 140-57

Danial., Ahmad Fariez, (2018). 'Analisis Pemahaman Pajak Penghasilan Dan Sanksi Pajak Pada Wajib Pajak Orang Pribadi (Wp Op) Pegawai Ud Petis Udang Di Kampung Petis

Desa Gumeng Bungah Gresik' (Universitas Islam Negeri Sunan Ampel Surabaya)

Fadiyah Ramadhani Putri, (2020). 'Kebijakan Pemerintah Dalam Pengenaan Pajak 
Penghasilan Pelaku Usaha Asing Game Online',

Https://Jurnal.Narotama.Ac.Id/Index.Php/Hukumbisnis/Article/View/1014, 4, 254-

$70<$ https://doi.org/10.31090/hukumbisnis.v4i1.1014>

Hermanda., Atika, Ujang Sumarwan., and Netti Tinaprilla., (2019). 'The Effect of Social

Media Influencer on Brand Image, Self-Concept, and Purchase Intention', Journal of Consumer Sciences, 4, 76-89 <https://doi.org/https://doi.org/10.29244/jcs.4.2.7689>

'Istilah “Anak”, “Anak”, Dan "Belum Dewasa” - Pengadilan Negeri Kediri', Http://PnKediri.Go.Id/Index.Php/Component/K2/Item/230-Istilah-Anak-Dan-BelumDewasa.Html, 2017

Mustika, Candra, (2012). 'Pajak Penghasilan Di Indonesia (Peraturan,Perhitungan Dan Upaya Peningkatan Potensi Penerimaan) Dan Kaitannya Dengan Invetsasi Di Indonesia', Mankeu, Vol. 1, 227-38

Wiratraman, Herlambang P, (2008). Penelitian Sosio-Legal Dan Konsekuensi Metodologisnya, Https://Herlambangperdana.Files.Wordpress.Com/2008/06/Penelitian-Sosio-LegalDalam-Tun.Pdf,

Yani, Sona, and Menik Siwi, (2020). 'Analisis Penggunaan Media Sosial Dan Sumber Belajar Digital Dalam Pembelajaran Bagi Siswa Digital Native Di SMAN 2 Painan', Jurnal Pendidikan Ekonomi, 13, 1-7

<https://doi.org/10.17977/um014v13i12020p001> 